\title{
Biopsychosocial conditions of Mexican older adults with diabetes mellitus
}

\author{
Eduardo Guzmán-Olea ${ }^{1,2}$, David López-Romero², Kirvis Torres-Poveda ${ }^{3,4}$, Vicente Madrid-Marina \\ José Luna-Muñoz ${ }^{5}$, Bertha Maribel Pimentel-Pérez ${ }^{2}$ and Raúl Azael Agis-Juárez² \\ ${ }^{1}$ Research Fellow, Consejo Nacional de Ciencia y Tecnología (CONACYT), Gerontology Academic Area, Instituto de Ciencias de la Salud (ICSA), \\ Universidad Autónoma del Estado de Hidalgo (UAEH); ${ }^{2}$ Gerontology Academic Area, ICSA, UAEH, San Agustín Tlaxiaca, Hgo.; ${ }^{3}$ CONACYT, Instituto \\ Nacional de Salud Pública de México (INSP) Cuernavaca, Mor.; ${ }^{4}$ Center of Research on Infectious Diseases, INSP; ${ }^{5}$ National Brain Bank, LaNSE, \\ CINVESTAV, Ciudad de México, Mexico
}

\begin{abstract}
Diabetes mellitus (DM) is a global health problem, which significantly affects older adults. Objective and methods: The prevalence and biopsychosocial conditions of DM in older adults in the State of Hidalgo, Mexico, are analyzed using the Health and Aging Survey 2014 (SABE-Hidalgo, Mexico). Results: DM in older adults presents a prevalence of $28.22 \%$ in the State, predominating in women and becoming more common with increasing age. The highest frequency occurs in residents of urban areas (57.2\%), those with less schooling (79.6\%), and those who live with relatives $(77 \%)$. In addition, $54.7 \%$ of older adults with DM had cognitive impairment, $67.9 \%$ had arterial hypertension and $45.28 \%$ presented joint disease. $41.2 \%$ suffered falls, $68.52 \%$ visual problems and $87.3 \%$ tooth loss. Finally, $85.8 \%$ receive care but only $29.2 \%$ perceive improvement in their health. Conclusions: It is fundamental to develop integral programs and policies to care for older adults with DM.
\end{abstract}

KEY WORDS: Biopsychosocial. Older adults. Diabetes mellitus.

\section{Introduction}

Diabetes mellitus (DM) is currently considered one of the main public health problems in the world, with around 371 million cases and an estimated increase to 439 million cases for the year 20301,2. In Mexico, according to the National Institute of Geography and Informatics (INEGI - Instituto Nacional de Geografía e Informática), in the year 2012, DM constituted the second cause of death and it projects an increase of $23.9 \%$ by the year 2030; in addition, it generated an annual expenditure of USD $452,064,988$ for its care in 2010, a figure that has increased in recent years ${ }^{3}$. Importantly, the population groups with higher incidence of the disease are those of women and older patients; in particular, the latter age group has important physiological characteristics and comorbidity that influence on the development of the disease ${ }^{4}$, while those who already have the disease develop vascular, bone density, mental, heart and auditory complications, and suffer falls, chronic pain and depression, which may impact on a reduction in life expectancy of between 5 to 10 years ${ }^{5-10}$. In this sense, in spite of the above-mentioned considerations, the regulatory framework in Mexico for the prevention, treatment and control of DM (Mexican Official Standard NOM-015SSA2-2010) ${ }^{11}$ does not consider a specific section for the care of the older adult population. In spite of the current relevance of the presented subject, in Mexico there are few publications on the epidemiological panorama, health conditions and intervention programs focused on the older adult population with DM, and this is why the present study shows the prevalence of DM and the biopsychosocial conditions of a

\section{Correspondence:}

Eduardo Guzmán-Olea

Circuito Ex Hacienda La Concepción, s/n Carretera Pachuca Actopan

Date of reception: $15-12-2016$

Date of acceptance: 30-12-2016

C.P. 42160, San Agustín Tlaxiaca, Hgo., México

E-mail: eguzmanol@conacyt.mx
DOI://dx.doi.org/10.24875/GMM.M18000082
Gac Med Mex. 2017;153:718-722

Contents available at PubMed www.gacetamedicademexico.com 
population group of Mexican older adults who suffer from the disease.

\section{Method}

The performed analysis uses information obtained by the Health, Wellbeing and Aging (SABE - Salud, Bienestar y Envejecimiento) Survey, carried out in 2014 in the State of Hidalgo, Mexico. The description of the design and methodology has been validated and previously described, and is representative at the State level ${ }^{12,13}$. The analysis was conducted based on the sections related to sociodemographic characteristics, self-reported medical conditions, coverage and health status, cognitive status, motor ability and health status perception. The sample corresponds to 2503 older adults, residents of randomly selected households from urban and rural areas. The survey was applied by pairs of interviewers from the Gerontology Academic Area of the Autonomous University of the State of Hidalgo (UAEH -Universidad Autónoma del Estado de Hidalgo) who were trained by the Care of Aging Area of the National Center of Preventive Programs and Disease Control (CENAPRECE - Centro Nacional de Programas Preventivos y Control de Enfermedades) of the Ministry of Health.

- Study population: participants were adults older than 60 years who affirmatively answered the literal question "has a doctor or nurse ever told you that you have diabetes, i.e. high blood sugar values?"

- Sociographic data: information corresponding to age, gender, place of residence, people sharing the household and level of education (expressed as none or having concluded basic education vs. having received any education higher than basic education).

- Cognitive status: to assess the cognitive status, Folstein's test-type Mini-mental State Examination questionnaire was applied ${ }^{14}$.

- Motor functionality: those who affirmatively answered having regularly practiced exercise or rigorous physical activities, such as sports, jogging, dancing or heavy work thrice-weekly during the previous 12 months were defined as older adults with motor functionality.

- High blood pressure diagnosis: older adults with previous diagnosis of DM who positively answered the question: "has a doctor or nurse ever told you that you have high blood pressure, i.e., arterial hypertension?"
- Motor ability: older adults with previous DM diagnosis who referred having suffered at least one fall within the previous 12 months.

- Vision: it was determined by the answer to the question "how good is your eyesight (without glasses or contact lenses) to see from the distance (such as to recognize a friend on the other side of the street?"

- Diabetes care and perception of improvement: older adults who referred taking any medication (oral or insulin injections), following a special diet or losing weight to control diabetes, and the perception on their health after 12 months' treatment.

- Tooth loss: tooth loss and number of missing pieces were determined by personal statement confirmed by oral examination.

A descriptive and dispersion analysis was performed for the sociodemographic, biological and health self-perception data using the Statistical Package for the Social Sciences (SPSS Inc., Chicago, Illinois, USA), Version 15.0 for Windows, with the results being expressed as means or proportions, considering the standard deviation/error; in addition, the weighing factors and the survey design were considered to obtain population estimators. The calculation of the proportion differences between genders (males/ females), place of residence (urban/rural), company in the household (living alone or accompanied), level of education (basic or less vs. higher than basic) and age (60 to 69 and 70 years or more) was carried out using the Z-test with a level of significance of $95 \%$ $(p<0.05)$.

The research project was authorized by the Research Commission of the Gerontology Academic Area of the UAEH. The surveys and the study in general were conducted considering all ethical aspects of the Ministry of Health and the recommendations for research in human subjects of the 1964Declaration of Helsinki. For the performance of the project, informed consent and authorization was obtained from the participants.

\section{Results}

The State of Hidalgo 2014 SABE survey collected information of 2503 older adults, aged from 60 to 103 years, residents of urban and rural areas. Of total surveyed subjects, those who were incapable to answer or who referred not knowing about having DM were eliminated and thus the final sample was 
Table 1. Sociodemographic characteristics of older adults with diabetes mellitus by groups of age, gender, place of residence, company in the household and level of education

\begin{tabular}{|c|c|c|c|c|c|c|c|c|c|c|c|}
\hline \multirow[t]{2}{*}{ Condition } & \multirow[t]{2}{*}{$\begin{array}{l}\text { Total } N=2484 \\
(100 \%)\end{array}$} & \multicolumn{2}{|c|}{ Age (years) } & \multicolumn{2}{|c|}{ Gender } & \multicolumn{2}{|c|}{$\begin{array}{l}\text { Place of } \\
\text { residence* }\end{array}$} & \multicolumn{2}{|c|}{$\begin{array}{l}\text { Company } \\
\text { in the } \\
\text { household }^{\dagger}\end{array}$} & \multicolumn{2}{|c|}{ Level of education } \\
\hline & & $60-69$ & $70+$ & M & $\mathbf{F}$ & Urban & Rural & A & C & Basic or less & Higher than basic \\
\hline Referred DM (\%) & $\begin{array}{c}701 \\
(28.2)\end{array}$ & $\begin{array}{c}332 \\
(47.4)\end{array}$ & $\begin{array}{c}369^{\ddagger} \\
(52.6)\end{array}$ & $\begin{array}{c}206 \\
(29.4)\end{array}$ & $\begin{array}{c}495^{\ddagger} \\
(70.6)\end{array}$ & $\begin{array}{c}401^{\ddagger} \\
(57.2)\end{array}$ & $\begin{array}{c}300 \\
(42.8)\end{array}$ & $\begin{array}{l}161 \\
(23)\end{array}$ & $\begin{array}{l}540^{\ddagger} \\
(77)\end{array}$ & $\begin{array}{c}558^{\ddagger} \\
(79.6)\end{array}$ & $\begin{array}{c}143 \\
(20.4)\end{array}$ \\
\hline
\end{tabular}

${ }^{*}$ According to INEGI, a settlement is considered to be rural when it has less than 2500 inhabitants $^{6}$.

tThe category comprises older adults.

¥Statistically significant difference between groups, with $P<0.005$ adjusted by sample complex design

C: with company; A: alone.

Source: own creation.

Table 2. State of comorbidity, motor ability and diabetes mellitus control in older adults

\begin{tabular}{|c|c|c|c|c|c|}
\hline \multicolumn{6}{|c|}{ Older adults referring suffering from DM ( $n=701 ; 100 \%)$} \\
\hline Condition & $\begin{array}{c}\text { HBP } \\
\%(95 \% \mathrm{Cl})\end{array}$ & $\begin{array}{l}\text { Arthrosis } \\
\%(95 \% \mathrm{Cl})\end{array}$ & $\begin{array}{c}\text { Cognitive impairment } \\
\%(95 \% \mathrm{Cl})\end{array}$ & $\begin{array}{l}\text { Performance of physical } \\
\text { activities } \%(95 \% \mathrm{Cl})\end{array}$ & 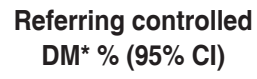 \\
\hline Present & $\begin{array}{c}67.7 \\
(67.19-68.22)\end{array}$ & $\begin{array}{c}45.3 \\
(44.16-46.44)\end{array}$ & $\begin{array}{c}54.9 \\
(56.15-56.16)\end{array}$ & $\begin{array}{c}49.2 \\
(47.66-50.74)\end{array}$ & $\begin{array}{c}85.8 \\
(84.4-87.2)\end{array}$ \\
\hline Not present & $\begin{array}{c}32.3 \\
(31.09-33.51)\end{array}$ & $\begin{array}{c}54.6 \\
(53.46-55.74)\end{array}$ & $\begin{array}{c}45.1 \\
(43.85-46.36)\end{array}$ & $\begin{array}{c}50.8 \\
(49.26-52.34)\end{array}$ & $\begin{array}{c}14.2 \\
(12.7-15.6)\end{array}$ \\
\hline $\begin{array}{l}\text { Difference } \\
P \text { value }\end{array}$ & 0.000 & 0.000 & 0.000 & 0.000 & 0.000 \\
\hline
\end{tabular}

${ }^{*}$ Comprises older adults who claimed the disease was controlled with pharmacological therapy, special diet or physical activity.

DM: diabetes mellitus; HBP: high blood pressure; $95 \% \mathrm{Cl}$ : 95\% confidence interval.

Source: own creation.

comprised by 2484 older adults. Out of total participants, $28.22 \%$ referred suffering from the disease (95\% confidence interval [Cl]: 27.84-28.57]), with a predominance of females being observed, with $70.6 \%$ of cases $(Z=2.0 ; p<0.05)$, and a trend towards increasing the number of cases as age advances $\left(X^{2}{ }_{1 g l}=4.3 ; p<0.05\right)$. As for the place of residence, people from urban areas suffer from the disease more frequently than those who dwell in rural areas (57.2\% vs. $42.8 \% ; p>0.05)$; in addition, when company in the household was analyzed, $77 \%$ of older adults who refer DM were observed to live with company $(p<0.05)$. Furthermore, older adults with no education or with low levels of education were observed to have the disease less frequently (79.6\%) (Table 1 ).

Comorbidities and physical activity performance of older adults who suffer from DM are reported in table 2. When the duality of suffering from DM and high blood pressure was analyzed, $67.4 \%$ of older adults were observed to have both conditions (95\% Cl: 67.19-67.61). Moreover, out of total patients with DM, 45.3\% (95\% Cl: 44.16-46.44) referred suffering from arthritis, rheumatism or arthrosis. When the cognitive status was analyzed, $54.9 \%$ (95\% IC: $56.15-$ 56.16) of those who suffer from DM were found to have memory alterations with some degree of cognitive impairment, whereas when the functional capacity was assessed, 50.8\% (95\% Cl: 49.26-52.34) had motor difficulties, and therefore do not perform physical activities such as sports, jogging, dancing or physical work on a regular basis.

Table 3 shows visual and motor ability, tooth loss and perceived health status of older adults who suffer from DM after receiving medical care during the previous year. As it can be observed, more than $87 \%$ has lost at least one tooth, while, importantly, $53.4 \%$ has lost at least 5 teeth. On the other hand, $68.5 \%$ of subjects referred having difficulty seeing far away without using glasses and, in addition, in $41.2 \%$ was at least one fall recorded within the 12 months prior to the interview. Finally, when the perception on health status was analyzed, $70.7 \%$ referred feeling the same or worse in spite of having been receiving pharmacological treatment, special diet or having practiced physical activity during the previous 12 months.

\section{Discussion}

Over the past few years, Mexico has faced the DM epidemics as one of its major health challenges. 
Table 3. Visual and motor ability, tooth loss and perceived health status in older adults with diabetes mellitus

\begin{tabular}{|c|c|c|c|c|c|c|c|c|c|c|}
\hline \multicolumn{11}{|c|}{ Older adults referring to suffer from DM $(n=701 ; 100 \%)$} \\
\hline \multirow{2}{*}{$\begin{array}{l}\text { Condición } \\
\text { Status }\end{array}$} & \multicolumn{3}{|c|}{ Referred tooth loss $\%(95 \% \mathrm{Cl})$} & \multicolumn{2}{|c|}{$\begin{array}{l}\text { Perceived vision } \\
\quad \%(95 \% \mathrm{Cl})\end{array}$} & \multicolumn{3}{|c|}{ Referred falls \% (95\% Cl) } & \multicolumn{2}{|c|}{$\begin{array}{c}\text { Self-perceived health status } \\
\qquad \%(95 \% \mathrm{Cl})\end{array}$} \\
\hline & 0 & $1-4$ & $5+$ & G & $\mathrm{B}$ & 0 & $1-3$ & $4+$ & Better & Same or worse \\
\hline & $\begin{array}{c}12.6 \\
(11.5-13.8)\end{array}$ & $\begin{array}{c}34 \\
(32.9-35.2)\end{array}$ & $\begin{array}{c}53.4 \\
(52.3-54.6)\end{array}$ & $\begin{array}{c}31.5 \\
(30.1-32.8)\end{array}$ & $\begin{array}{c}68.5 \\
(67.1-69.9)\end{array}$ & $\begin{array}{c}58.8 \\
(57.3-60.4)\end{array}$ & $\begin{array}{c}33.9 \\
(32.4-35.5)\end{array}$ & $\begin{array}{c}7.3 \\
(5.8-8.9)\end{array}$ & $\begin{array}{c}29.3 \\
(69.2-72.3)\end{array}$ & $\begin{array}{c}70.7 \\
(69.2-72.3)\end{array}$ \\
\hline $\begin{array}{l}\text { Difference } \\
\text { p-value }\end{array}$ & 0.000 & 0.000 & 0.000 & 0.000 & 0.000 & 0.000 & 0.000 & 0.000 & 0.000 & 0.000 \\
\hline
\end{tabular}

B: bad; DM: diabetes mellitus; G: good; 95\% Cl: 95\% confidence interval.

Around 6.4 million adults with medical diagnosis of the disease have been reported to currently exist; howev$\mathrm{er}$, in spite of different strategies and policies focused on its containment and control, a growing trend in the incidence and prevalence of the pathology is observed, possibly associated with the Mexicans' lifestyles and the shift in the population age ${ }^{15}$. In this sense, Mexico is facing a progressive change of the older adult population, which shows particularly important conditions characterized by insufficient access to social security on health, educational lag and multidimensional poverty ${ }^{16}$; furthermore, the scarcity of reports on the specific health conditions of this age group has limited the generation of strategies, programs, actions and health policies focused on comprehensibly addressing their needs. It is also essential to generate regional information that enables establishing specific actions according to the particular needs of each sector and condition and, although some of the findings herein presented are consistent with national and international trends ${ }^{17}$, the results regarding the place of residence are opposed to those reported by other authors ${ }^{10}$, possibly due to the access (in kind and purchasing capacity) to a larger variety of industrialized foods and to the lifestyle. On the other hand, the higher frequency of DM in older adults who live with was made evident; in this sense, the causes of such condition remain to be investigated since, although lifestyle-based approaches have been proposed in other population groups ${ }^{17-19}$, factors such as family exclusion (for having the disease or being old), the difficulty to adequately and efficaciously eat (due to economic, psychological, anatomical and functional factors) and the difficulty to have access to information about attention and care when there is incapacity to read and write, are present in older adults.

In the case of comorbidity, in particular the DM and high blood pressure dyad, the presented frequencies are in agreement with the national reality (around
$70 \%$ ). With regard to control of this condition, the relationship held by an adequate diet and the performance of physical activity has been widely documented ${ }^{17,19}$; however, comprehensive assessment has been recommended ${ }^{20,21}$ also considering joint disease, risk of falls, visual capacity evaluation and functional (physical and mental) grade. In this sense, the findings herein presented unravel the fact that although $85 \%$ of older adults with DM refer having the disease under control (by means of pharmacological therapy, special diet or by performing physical activity), only $29.3 \%$ perceive improvement in their health condition, and although half the patients perform physical activities as part of the control of their disease, $45.3 \%$ refer having been diagnosed with arthrosis, $68.5 \%$ consider having poor vision without glasses and $41.2 \%$ has experienced at least one fall within the last 12 months. Among those who suffer from DM, 54.9\% are also observed to have memory loss and some degree of cognitive impairment, which complicates self-care activities, generates some type of dependence and drives to the need for primary caregivers for their care. In addition, although the diet is fundamental for adequate control of the disease, the presented results demonstrate that only $12.6 \%$ of the study population preserved all their teeth, while more than $50 \%$ had at least 5 pieces missing, which modifies the type and variety of foods they can consume, and in some cases it affects self-esteem and causes a lack of interest in participating in group intervention activities. Finally, although many of the social security institutions of the country have developed and implemented specific programs for the care of affiliated older adults in matters of DM control, treatment and follow-up ${ }^{21}$, there are still several conditions (such as those herein presented) that are not considered in their care programs. Furthermore, in the face of the recent National Agreement towards Universalization of Health Services ${ }^{22}$, homologation of criteria and guidelines to be followed is 
essential for the prevention, treatment and control of the disease, at the national level and at all State institutions that provide health services, and fundamentally subscribing the specific plan of action for the comprehensive care of the population of older adults with DM. The regulatory framework that might unify such actions is the Mexican Official Standard NOM-015-SSA2-2010, but multi-level actions, decisions and proposals are required, which must be considered. The results of the present study identify and locate some of the elements that might be considered in order to improve the care of older adults who suffer from DM.

\section{Conclusion}

The increasing prevalence of DM in older adults in Mexico requires an update of regulatory elements for the prevention, treatment and control of the disease, as well as the generation of a national plan of action involving all State institutions that provide health services, based on a comprehensive approach to the disease that includes the biopsychosocial aspects of this population group.

\section{Acknowledgements}

To PAHO/WHO Mexico, which granted CENAPRED permission to use its Protocol of Health, Wellbeing and Aging for the conduction of this study in the entire country. To the Ministry of Health, for the funding for the conduction of the Hidalgo 2014 SABE survey.

\section{References}

1. Shaw JE, Sicree RA, Zimmet PZ. Global estimates of the prevalence of diabetes for 2010 and 2030. Diabetes Res Clin Pract. 2010;87:4-14.

2. Sistema Nacional de Vigilancia Epidemiológica. Base de datos del Sistema de Notificación Semanal SUAVE (información preliminar)/DGAE Secretaría de Salud, 1998- 2012. México; SSa, 2013. (Consultado el 15 de agosto de 2016.) Disponible en: http://www.epidemiologia.salud.gob. $\mathrm{mx} /$ doctos/infoepid/bol_diabetes/dm2_bol1_2013.pdf el

3. Rodríguez-Bolaños RA, Reynales-Shigematsu LM, Jiménez-Ruiz JA et al. Costos directos de atención médica en pacientes con diabetes mellitus tipo 2 en México: análisis de microcosteo. Reva Panam Salud Publica. 2010:28:412-20.
4. Gutiérrez-Hermosillo H, Díaz de León-González E, Pérez-Cortés P, et al. Prevalencia de diabetes mellitus de tipo 2 y factores asociados en la población geriátrica de un hospital general del norte de México. Gac Med Mex. 2012;148:14-8.

5. Ducharme N, Radhamma R. Hyperlipidemia in the elderly. Clin Geriatr Med. 2008;24:471-87.

6. Aguilar-Salinas CA, Monroy OV, Gómez-Pérez FJ, et al. Characteristics of patients with type 2 diabetes in México: results from a large population-based nationwide survey. Diabetes Care. 2003;26:2021-6.

7. Villalpando S, Shamah-Levy T, Rojas R, et al. Trends for type 2 diabetes and other cardiovascular risk factors in Mexico from 1993-2006. Salud Publ Mex. 2010;52(Supl 1):S72-9.

8. Aguilar-Salinas CA, Rojas R, Gómez-Pérez FJ, et al. Prevalence and characteristics of early-onset type 2 diabetes in Mexico. Am J Med. 2002;113:569-74

9. Ortiz-Domínguez ME, Garrido-Latorre F, Orozco R, et al. Sistema de protección social en salud y calidad de la atención de hipertensión arterial y diabetes mellitus en centros de salud. Salud Publ Mex. 2011; 53:436-44.

10. Hernández-Ávila M, Gutiérrez JP, Reynoso-Noverón N. Diabetes mellitus en México. El estado de la epidemia. Salud Publ Mex. 2013;55(Supl 2): S129-36.

11. Secretaría de Salud. Norma Oficial Mexicana para la prevención, tratamiento y control de la diabetes mellitus. NOM-015-SSA2-2010. México: Diario Oficial de la Federación; 2010. (Consultado el 25 de julio de 2016.) Disponible en: http://dof.gob.mx/nota_detalle.php?codigo=5168074\&fecha=23/11/2010

12. Lozano ME, Calleja J, Mena R et al. Investigación clinicoepidemiológica en envejecimiento: metodología del proyecto Encuesta Salud, Bienestar y Envejecimiento (SABE) en México. Revista de la Sociedad Peruana de Medicina Interna. 2011;24:186-98.

13. Secretaría de Salud, Programa Nacional de Atención al Envejecimiento, CONAEN. Resultados de la Encuesta Salud, Bienestar y Envejecimiento (SABE Hidalgo). Publicación Secretaría de Salud; 2016. p. 21-85.

14. Folstein MF, Folstein SE, McHugh PR. Mini-mental state: a practical method for grading the cognitive state of patients for the clinician. J Psychiatr Res. 1975;12:189-98.

15. Villalpando $S$, Rojas R, Shamah-Levy $T$, et al. Prevalence and distribution of type 2 diabetes mellitus in Mexican adult population. A probabilistic survey. Salud Publ Mex. 2010;52(Supl 1):S19-26.

16. Dirección General de Información en Salud. Proyecciones de la población de México 1990-2030. México: CONAPO; 2010. (Consultado el 12 de junio de 2016.) Disponible en: http://pda.salud.gob.mx/cubos/cconapo2010proy.html

17. Gutiérrez JP, Rivera-Dommarco J, Shamah-Levy T, et al. Encuesta Nacional de Salud y Nutrición 2012. Resultados nacionales. Cuernavaca, México: Instituto Nacional de Salud Pública; 2012.

18. Aguilar-Salinas $C A$, Hernández-Jiménez $S$, Hernández-Ávila $M$, et al Acciones para enfrentar a la diabetes. Documento de postura. México: Academia Nacional de Medicina; 2015

19. Goedecke JH, Ojuka EO. Diabetes and physical activity. Med Sport Sci. 2014;60:122-9.

20. Guzmán-Olea E, Pimentel-Pérez BM, Salas-Casas A, et al. Prevención a la dependencia física y al deterioro cognitivo mediante la implementación de un programa de rehabilitación temprana en adultos mayores institucionalizados. Acta Universitaria. 2016;26:97-103.

21. Instituto Mexicano del Seguro Social (IMSS). Diagnóstico y tratamiento de diabetes mellitus en el adulto mayor vulnerable. México: CENETEC; 2013. (Consultado el 9 de agosto de 2016.) Disponible en: http://www. cenetec.salud.gob.mx/descargas/gpc/CatalogoMaestro/imss 657 13 dxytxdedmenadultovulnerable/imss_657_13_dxytxde_dm_en_adultovulnerableger.pdf

22. Secretaría de Salud. Acuerdo nacional hacia la universalización de los servicios de salud. México: Ssa; 2016. (Consultado el 6 de septiembre de 2016.) Disponible en: https://www.gob.mx/cms/uploads/attachment/ file/76997/ACUERDO_NACIONAL_FIRMADO_7_ABRIL_2016.pdf 